\title{
Social Myths: A New Approach
}

\author{
Gérard Bouchard \\ Université du Québec à Chicoutimi
}

\begin{abstract}
Nowadays, the study of myths is rather neglected as a field of research in sociology. There is a void that this paper would like to contribute to filling. It outlines a theoretical and empirical sociological approach to social myths as a major component of collective imaginaries and a universal sociological mechanism through time and space. The article recalls the major functions performed by myths in every society (modern as well as "primitive"), introduces new concepts, and sets forth an analytical framework designed to account for the emergence, the reproduction, and the decline of myths, as sacralised collective representations.
\end{abstract}

Keywords: social myths, archemyths, mythification process, discursive strategies

This paper ${ }^{1}$ addresses the topic of social myths as sacralised collective representations, more specifically sacralised values. It parts company with the deep analytical divide that has been created between myths in "primitive" and in modern societies. It rather posits that myths are active in both, although in different ways. It also rejects Lévi-Strauss’s approach to myths insofar as it does not make room for emotion, which I consider a central component, and it largely ignores the major role of social actors in the production of myths.

\section{Myth as a Universal Mechanism}

In all societies, a welter of ideas are regularly set forth and circulated as to how a society should be defined, what set of values and ideals should be pursued, what symbolic resources should nurture identities, what role a society should assign itself in the world, what episodes of its past should be celebrated and emulated, and the like. How to explain that while most of those ideas will be quickly forgotten, some, down the road, will acquire an enduring and transcending authority verging on sacredness, such that they can impose themselves upon the minds and strongly bear on individual and collective behaviours? Likewise, in every society, one can identify deep emotional issues, vibrant sensitivities, widely endorsed "truths" that structure the worldviews, feed public debates, and inform public policies. Where do they come from? How did they emerge? And how are they reproduced? In other words, history strongly predisposes the members of a society in favour of deep feelings and ideals that feed identities and motivations. Through what process and with what consequences is this achieved?

Here are a few well known examples of such highly valued ideals that are so deeply ensconced in national creeds that they are taken for granted and hardly questioned: racial equality in South Africa, freedom and individual property in the United States, universality and equality of citizenship rights in France, celebration of ethnic diversity in multiculturalist English Canada, social equality and justice in former colonies of Europe, democracy in former dictatorships, gender equality just about everywhere in the Western world. Again, the

Gérard Bouchard, senior professor in History and Sociology, Department of Social Sciences, Université du Québec à Chicoutimi, Canada; main research fields: Social and National Myths, Collective Imaginaries. 
purchase of these values is so strong that one usually refrains from challenging them. Thanks to their sacredness, the symbolic contents of myths allow them to largely escape criticism, unlike other collective representations. The nation and its transcending symbols offer another example: battlefields and military cemeteries are sanctuaries (who would dare to scream and exchange jokes in those venues?); the tomb of the unknown soldier commands reverence; memory of war heroes is untouchable; burning the flag is a profanation, etc.

Again, what about the mechanism that governs this valorization process? And more generally, how to account for the sacralization that allows some ideas and symbols to largely shield themselves from critical examination?

As basic and consequential as they appear to be, those questions are far from being satisfactorily answered by sociological analysis. Surprisingly, current social sciences devote little attention to those exceptionally powerful symbolic devices at work in all societies, except for the perfunctory condemnations of hardship and atrocities associated with myths, as it indeed tragically happened and is still happening across the world. ${ }^{2}$ Other than that, myths are perceived either as lies, as harmless legends and fictions, or as a feature that belongs to pre-modern societies. In contrast to this common view, it can be argued that myths are the most powerful collective representations operating in contemporary societies. As such, they should be brought back in the mainstream sociological analysis.

The relevance of this proposal is hardly disputable. As carriers of deeply seated, even sacralized values, ideals and beliefs, myths heavily bear on the course of a society by providing institutions with the required symbolic foundations that secure their reach. They inform worldviews, ideologies, identities, and solidarities. They allow societies to mobilize around long-term goals, to better manage their divisions, to respond energetically to crises and traumas. And they infuse nations with a sense of who they are and what they should do. Conversely, myths can also disable, induce apathy, help maintain people in dependence and oppression, feed cleavages and conflicts, trigger violence (their association with extreme forms of nationalism is notorious), and serve as a tool for social domination. Moreover, all societies host a set of untold and unutterable "truths" that they are reluctant to face. These blind spots speak to the taboo dimension of myths, which thus can be said to conceal as much as they reveal.

Whatever the scenario, the study of myths provides a pathway into the dark realm of emotions and deep symbols that stimulate reason and ultimately drive action.

\section{Social Myth}

One must transcend the common perception that reduces the concept of myth either to an innocuous fiction (a fable, a legend) or to a deceptive, alienating, and potentially dangerous discourse. This is a restricted view of myths since they can also promote lofty ideals such as freedom, equality, democracy, and peace (aren't these said to be the "founding myths" of the Western world?). Fundamentally, social myths are a specific type of collective representations (beneficial or harmful) that convey values, beliefs, and aspirations. They must be construed as a universal sociological feature, which means that there are no myth-less or myth-free societies and it is pointless to wonder if they should be admitted or rejected since they are there no matter what.

One characteristic of myths is to be highly hybrid collective representations. A social myth is always an unevenly calibrated mixture of reality and fiction (myths are both factual and fictional), of reason and emotion, of consciousness and unconsciousness, of truth and falseness. The analysis of myths invites to straddle such 
dichotomies. As a result, myths must be evaluated on the basis of their overall efficacy rather than their veracity. This, of course, is not meant to suggest that the normative dimension is irrelevant; simply, it belongs to a different approach.

Social myths should not be confused with ideologies. The latter are rational, coherent (ideally), and elaborate discursive constructions designed to justify a political orientation or a social course of action. But in doing so, ideologies always tap into some myths (or symbols through which they operate) that serve as widely shared, unquestionable moral goals (freedom, social justice, solidarity, etc.). In other words, social myths inform ideologies.

Finally, the foregoing makes clear that I reject the evolutionist view suggesting that myths are characteristic of pre-modern communities while ideologies are typical of modern societies, as forcefully argued by G. Balandier (1962).

\section{The Mythification Process}

I conceive social myths as the by-product of a dynamic framework comprising eight units or modules that combine to articulate a powerful message. Together, they account for the mythification process. What follows is a brief reconstitution that relies on both theory and empirical observation.

(1) A structuring event or episode acting as an anchor. It is a particularly meaningful, determining experience that has occurred in the near or distant past of a collectivity. Very often, it is a misfortune, a trauma, but it can also be a positive or gratifying accomplishment. Yet, it is always a choice made by social actors on behalf of a group or a whole society among several or many possibilities. Being chosen, a cultural trauma is also, to a large extent, a construct, as N. Smelser (2004) has pointed out.

(2) An imprint, that is, a deep emotion generated by the anchor in the collective consciousness. For instance, in the case of a traumatizing episode, the imprint will be informed by the sense of a wound and it will foster an enduring expression of suffering. By contrast, an imprint linked to a positive anchor will feed a sense of confidence and power. All of this assumes that the activation of emotion is to a large extent a social process, as has been shown by W. M. Reddy (2001). Indeed, there is no automatism here; social actors build the appropriate emotions from chosen anchors.

(3) The translation of the imprint into an ethos (values, ideals, beliefs). For example, the quest for equality, social justice and democracy can be generated by a feeling of unfairness linked to an experience of rights violation. Similarly, an episode of collective humiliation can foster a craving for an assertion of pride. The memory of slavery or genocide will result in a cult for racial equality and human dignity. Nations that have suffered from despotism may develop a distrust of strong states and a yearning for individual freedom. A nation that has experienced and survived a civil war will be particularly sensitive to issues related to unity and solidarity. A fragile cultural minority permanently concerned about its future and constantly fighting for its survival will value cohesion, consensus, loyalty. A nation that has not behaved courageously under hardship (invasions, military confrontations, natural disasters) will seek to make up by prizing and yearning for self-respect and achievement. ${ }^{3}$ In short, a society will tend to cherish symbolic goods of which it has been deprived, virtues it has failed to display at crucial moments, or values for which it has successfully fought.

(4) The sacralization of the ethos, as a consequence of intense commemoration, might be the crucial step in the formation of a social myth. Here takes place a cognitive shift, a complex and intriguing phenomenon still poorly understood. Essentially, it occurs when, during the mythification process, reason takes a back seat to 
emotion as the mental driving force, a shift that opens the way to sacralization. A full-fledged social myth draws most of its authority from the fact that it partakes of sacredness. Still, one can act against a myth but there might be a heavy price to pay. ${ }^{4}$ This partly accounts for the robustness, the power, and the longevity of social myths.

(5) An archetypal underpinning. Overtly or covertly, social myths feed on the psyche, more specifically archetypes, by conjuring up universal images and symbols, primary emotional forces (drives, instincts), and deep mental structures such as: the sanctity of blood ties, the threatening other, re-birth or renaissance, betrayal, the mother-land, the scapegoat, the savior, the golden age, the apocalypse, etc.

Those five constituents of the mythification process directly relate to the genesis of a myth, being linked both logically and sequentially. Besides, three additional elements intervene rather tangentially, as they belong to a symbolic engineering designed to disseminate and to instill the initial message.

(6) A myth takes shape thanks to the construction of a narrative and a continuing process of remembrance intended to magnify the anchor, to activate or reactivate the imprint and to stimulate the ethos by re-actualizing them in accordance with the ever-changing contexts. As for the narratives proper, even when they are rationally produced by scientists, they usually build upon emotional devices (F. Polletta 2006).

Commemorative rituals are particularly instrumental in this regard. In the case of negative imprints, for instance, they may officially be intended to heal the wound but actually, they often have the effect of reopening it; thus, they revive the pain and they reload the myth. ${ }^{5}$ To that end, powerful archetypal images such as victimhood, sacrifice, betrayal, heroism, and faithfulness to ancestors are routinely conjured up. Because of their performative dimension, rituals are paramount. They translate abstract values into feelings through ceremonies that create or reinforce a sense of togetherness.

These comments provide a better understanding of the authority of a myth: To question or to reject it is tantamount to denying its underlying suffering, to desecrating the greatness of past feats, to downplaying the merit of sacrificed heroes, and to betraying. This is why full-fledged myths can resist contradicting evidence; questioning them prompts an emotional, if not an aggressive outburst rather a rational response.

(7) Operating on the same basis as narratives, persuasion techniques and strategies are used to craft, disseminate, and root the message. This component is active and pivotal in each of the preceding modules and phases. The spectrum of channels that can be used is manifold, from media, social sciences and political discourse to literature and arts, as well as the whole range of communicative devices that can be called upon, from visualization (G. Zubrzycki 2013a) to framing (E. Goffman 1974).

(8) The last module is the initial involvement of social actors or "symbolic entrepreneurs"6 who strategically construct and promote myths to advance their agendas in a particular context of power relations. This highlights the pivotal role of communication techniques designed for persuasion. However, social actors do not create myths from scratch. Rather, they activate or reactivate "dormant" facts and feelings. ${ }^{7}$

In the process of dissemination relying on coalitions, the polyvalence of a myth is uppermost, as well as the charisma of the torchbearers and the relay mechanism from one actor to another. That said, one should not underestimate the major acculturation work informally carried out at the micro-social level of the family, peer groups, school and community. And this, of course, includes the action of individuals themselves who appropriate and re-process the message such that they better fit their deep views and needs.

From the foregoing, one understands that myths per se are not narratives but they typically use them as a scaffolding. Likewise, a full-fledged myth is a collective representation that has gone through every step of the 
mythification process, leading to sacredness. It follows that, in a society, collective representations can exist as more or less mythified.

To the extent that they are strategically produced by social actors, myths can be construed as utilitarian constructs. However, once they have been internalized by individuals and imbedded in a collective imaginary, they take on a life of their own. From the production to the reception sides, they travel the journey from cold constructs to warm truths. ${ }^{8}$ From then on, thanks to the cognitive shift, they are not only rational effects of discourse and power games, they become powerful emotional engines of identification, mobilization, and action. At this stage, they have become so deep-seated in the collective and individual minds that they can go unnoticed. ${ }^{9}$

According to A. Swidler (1986), individuals strategically determine their conduct by making choices among symbolic resources that a society makes available. In this respect, social myths stand apart insofar as they are not readily a matter of choice; they are part of what S. Moscovici (1984) calls "prescriptive representations" (9-14). Their sacralised and emotional quality, combined with the strong social pressure that comes with it, substantially restricts the area for choice. Does a young Black really "choose" to endorse racial equality? Does a young British really feel free to reject alternatives to individual freedom and democracy? Is the deepest basis of an identity the result of a rational, strategic choice? Through powerful myths, culture can generate symbols that constrain and drive social action. ${ }^{10}$ This, however, does not preclude that myths can be instrumentalized by pragmatic, manipulating social actors coldly pursuing an agenda.

From the above, a broad definition emerges. Tapping into the unconscious but strategically produced and used, social myths are hybrid, enabling or disabling, harmful as well as beneficial collective representations, subjected to change, partly factual and partly fictional, emotionally more than rationally driven, which enjoy a sacred status and convey values and beliefs. ${ }^{11}$ Among these components, sacredness is front and centre: This is what basically distinguishes social myths from other collective representations.

This definition of myths owes much to Émile Durkheim in that it stresses the importance of the symbolic foundations of a society and it relates myths to the social dynamic as a whole. ${ }^{12}$ What I add is a strong concern for the strategic dimensions of myth-building as undertaken by social actors, an emphasis on emotion and deep archetypal structures, an analytical scheme designed to account for the emergence, the reproduction and the decline of myths, and the idea of a pyramidal structure of myths within a collective imaginary.

\section{Efficiency of Social Myth}

The mythification process can be a useful analytical tool in accounting for the emergence, the perpetuation and the decline of a myth. I assume that in a collectivity, any idea, message or symbol becomes influential depending on the strength and functionality of the apparatus underlying the mythification process. A myth loses its appeal among a population and becomes socially irrelevant when it conflicts with another incipient myth that offers a better match with new challenges. Some examples that come to mind are Poland (the sacrificed nation, traditional shield of European Christendom against assaults from Orient), Israel (the besieged, resilient nation with a mission), Japan (the homogeneous, "pure" nation facing the prospect of mass immigration because of its low fertility), and Québec (the small nation in search of a re-conquest). In all those societies, old founding myths are presently challenged by the powerful ideals conveyed by ethno-cultural diversification and globalization, specially pluralism and cosmopolitanism. ${ }^{13}$ 
More specifically, in addition to the emotional purchase of the anchor, to the strength of the narrative and to the power of the social actors, the efficiency of a myth hinges on a wide array of factors, of which I mention just a few.

Polysemy: the capacity of a message to carry simultaneously several meanings (sometimes competing, even incompatible), a factor potentially conducive to a wide currency, if not a consensus. It follows that some amount of ambiguity in the definition of a myth may be helpful, perhaps necessary. Polysemy matters all the more since the message must successfully go through a triple appropriation process involving (a) the initial social actors who decide to endorse and promote it, (b) other social actors who join or relay the former, and (c) the targeted publics.

Adaptability: the capacity to live on through changing settings and challenges, thanks to a process of constant redefinition and renegotiation. Spectacular examples are offered by the metamorphosis of the exodus narratives in the Western past (M. Walzer 1986), the evolution of the Republican myth (behind a facade of continuity) in France since the end of the 18th century (A. M. Thiesse 1997) and the numerous reconfigurations of the frontier myth in the United States (R. White et al. 1994).

Relevance: the capacity to address the anxieties and most pressing issues of an epoch by providing the right meanings and attending to the right needs of the population; in other words: to secure a popular basis and to efficiently match or dovetail with the overall setting. This means that the defining factors lie as much in the characteristics or the situation of a society as in the forms or the quality of the cultural objects, an argument that A. Swidler (1986) has strongly made.

Piggybacking: the capacity of a new myth to build on old, well established myths and symbols so as to partake of their authority. In this sense, new myths work insofar as they re-work the latter and use them as leverage. To this end, the new myth is presented as a simple extension or a corollary of the latter. The strategy is particularly useful when proponents of radical changes seek to make them more palatable to dissenters by wrapping them in a veil of continuity. ${ }^{14}$

\section{The Pyramidal Structure of Social Myths}

Two sets of social myths are found at the heart of any collective imaginary. The first set consists of a few basic assets that structure the symbolic foundation of a society and act as a matrix. These are rooted in the imprints and they express the deepest views and feelings (fears, frustrations, values, hopes, shame, pride...) from which people make sense of their lives. I call them master myths. For example, in the case of Québec, one thinks of the old sense of being a fragile cultural minority in North America compelled to constantly fight for its survival, which has imposed a strong duty upon successive generations. Another master myth is the longing for a re-conquest as well as a full collective emancipation nurtured on the experience of British colonial domination dating back to 1763 and the social exploitation endured under both colonial rule and the Catholic clergy (along with its allies within the professional bourgeoisie). These two master myths (there are a few others) have always been at the core of Québec nationalism.

In the same spirit, one thinks of the ethics of civic equality in France, social justice in Norway, racial democracy in Brazil, the American dream and exceptionalism in the United States, China as the humiliated nation-at least for the last century (Z. Wang 2012). As for English Canada, there is the need to distinguish itself by asserting a superior morality, particularly toward the United States, etc. These are just a few examples but every society, in the course of its history, develops its own set of master myths. 
Deep-seated, belonging to the F. Braudel's longue durée, the master myths change very slowly (their structuring power ensures their durability). In turn, they are periodically translated into what I call secondary myths in a derivative way. While retaining the spirit of the former, the latter are designed to deal more efficiently with the hopes and anxieties of an ever-changing society and to meet the particular challenges of a given time. That is the second set of social myths. For illustration purposes, let's consider a small nation (such as Israel) that, as a master myth, puts a premium on survival and solidarity stemming from a sense of fragility and external threat. Then, one may expect the emergence of a set of derivative myths focusing on community bonds, mutual trust and support, loyalty, integration, collective mobilization, and so forth. Conversely, in a more secure society where individualism is emphasized, very different derivative (or secondary) myths are likely to take hold: freedom, self-esteem, self-reliance, achievement, competition, social climbing, etc. Finally, where the quest for harmony and discipline is paramount, then it may translate into myths such as social cohesion, moral order, compromise, negotiation and dialogue.

This mechanism must also be envisaged in a dynamic way. In keeping with the moving contexts, a master myth will generate successive sets of derivative myths as the latter exhaust their potential for providing the right meanings and driving action efficiently. Thus, I. Tyrrell (2013) has shown how the exceptionalist master myth in the United States has appeared in various guises over the past. The myth of the frontier has undergone a similar thread of metamorphosis (R. White et al. 1994) as well as the American dream (J. Cullen 2003). Likewise, the master myth of uniqueness and purity has expressed itself in several ways in the history of Japan (S. Vlastos 2013). In all of these instances, through various figures, the master myths have survived up to the present time, having succeeded in overcoming different challenges. It has also been shown how Québec master myths have gone through several translations between the end of the 18th century and the 1960s (G. Bouchard 2013).

Consequently, the structure of a collective imaginary may be construed as a pyramidal architecture comprising a layer of rather stable master myths and a layer of transient, more context-dependent derivative myths. Overall, this configuration accounts for a puzzling, double characteristic of social myths as we know them in that they are both short-lived and durable. Derivative myths provide a society with the means to constantly adapt and change, sometimes through radical breaks with the past, while, thanks to the master myths, the society still keeps a sense of continuity and stability essential for its survival. This distinction also helps to shed light on the mixture of the embrace and division over social myths: The master myths are mostly consensual, but they can generate conflicting secondary myths (citizens may endorse discordant visions of justice, democracy, freedom, etc.).

Yet, change occurs at both levels, but at a different pace and at a different price. It can be anticipated that the replacement of derivative myths will be associated with a period of instability and uncertainty. If so, one can imagine that a change or a substitution at the level of the master myths will be even more distressing. Needless to say, societies are reluctant to engage in that kind of perilous and most destabilizing endeavour, and they tend to defer the dreaded prospect of an overhaul at that profound level. France provides a case in point. There is no shortage of analysts nowadays suggesting that this country is now confronting this kind of somersault, given the inability of the Republican myths (or, should I say: the present version of these myths) to properly manage new forms of ethno-cultural diversity. The same argument could explain why the racial democracy myth in Brazil manages to survive in spite of the persistence of well documented deep racially-based inequalities. 
Another major "architectural" feature pertains to the way prevailing myths (master or secondary) are related to each other. Two situations come to light. First, myths can align themselves and coalesce into a consistent arrangement, thanks to a dynamic of convergence or complementarity, a configuration that I call an archemyth. In this case, social myths become intertwined in such a way that the upgrading of one myth spills over onto the others, thus, producing a cumulating force that can pull a whole society in one direction. Besides, the emergence of an archemyth both denotes and facilitates connexions among social actors' agendas. This way, as a grand narrative structured around a core message, an archemyth generates a massive energy. However, I believe that such a symbolic alignment remains a rather rare occurrence in the history of a society.

An archemyth drove the 1960s Quiet Revolution in Québec, built on the ideal of the advancement and assertion of Francophones. A new set of derivative myths emerged, coalescing into a powerful configuration (collective social and economic promotion, end of colonialism, social equality, political autonomy, promotion of the French language, secularization, modernization...). Coextensively, a different archemyth was taking shape in English Canada, propelled by the double ideal of (a) a decent, caring society (a "world moral model”) and (b) a society distinct from and morally superior to the United States cast as a foil. Multiculturalism (non-discrimination, respect of diversity), non-violence, the apology of compromise rather than confrontation, collective discipline, social equality, universal health care, and the pursuit of world peace were the major supporting myths.

According to a second scenario, myths can contradict and oppose each other, which creates a situation of antinomy. Québec, again, is an interesting case in point. Among the two master myths mentioned earlier (the defence of the fragile, besieged minority and the quest for re-conquest), the former tends to inhibit and to disable whereas the latter enables. ${ }^{15}$ However, even though contradiction between myths is central to the issue of social change, a function of myths is also to overcome contradiction in such a way that, sometimes, an internally conflicting symbolic configuration can still operate efficiently. Yet, in their own way, both scenarios (archemyth and antinomy) are expected to significantly impact the course of a society.

Finally, strictly speaking, one could make room for a third, "in-between" scenario—hybridity—wherein social myths are somehow only juxtaposed or randomly connected together without generating a meaningful and consequential pattern.

\section{Conclusion: A Social Approach}

In terms of analytical potential and novelty, what does this approach to social myths, as outlined here, bring to cultural sociology?

First, it calls for a critical view of the primitive/modern culture dichotomy.

It sets forth a definition of social myths as a distinctive (and neglected) universal sociological mechanism active in all (including postmodern) societies.

It advocates a general approach to myths that seeks to bring out their social underpinning, irrespective of time, space, and discursive sources (religious, literary, political...).

It suggests to address social myths as discursive constructs tapping into deep symbolic structures (archetypes) and to connect them to change (origin, reproduction, decline, replacement), power relations, social actors and conflict. In this way, it combines a structural and a dynamic dimension. It also draws attention to the purchase of largely unconscious primary images and symbols weighing upon individual and collective life. In doing so, it assumes that, if reason is the major engine of thought, myth might well be the major engine of culture, thanks to its close connection with sacredness. 
It highlights the role of social actors in promoting symbolic features as well as the influence of the often constraining potential of social settings (particularly, competition and conflicts), but it also very strongly emphasizes the inner life and power of the deep images and emotionally grounded codes that drive individuals and groups.

Through the distinction between master and derivative myths, and otherwise, the approach suggests a linkage between the layers of deep mental structures and day-to-day symbolic resources.

The concepts of archemyth, antinomy, and hybridity open a new window for the exploration of collective imaginaries (particularly the national myths) and how they affect the course of a society. They also invite a new way of analysing cultural change.

At the empirical level, the mythification process provides a roadmap that helps accounting for the emergence and the fate of a social myth.

The approach invites to objectivise social myths, removed from any normative criteria, which allows for a sociological evaluation based on their symbolic efficacy.

Lastly, the approach shows a concern to take into account the various components of social myths and to decipher their interplay.

That being said, a lot remains to be done empirically and theoretically to validate and to refine this approach. Most of all, the sacralization process, and more specifically the attendant cognitive shift, must be better understood.

Finally, this essay has raised complex questions about social myths. It has also highlighted the power of those representations and the huge stakes involved for all societies. It is therefore hoped that the sociological community sees the urgency to devote more attention to this topic so as to advance our understanding of a powerful mechanism that can bring about both the best and the worst in a society.

\section{Notes}

1. This article has benefited from advice generously provided by William Sewell, Peter Hall, Michèle Lamont, Ann Swidler, and other members of the Successful Societies group of the Canadian Institute for Advanced Research. I also thank Alain Roy, Nathan Glazer, Chris Bail, Susan Hodgett, and Jean-Jacques Wunemburger for their help (although the usual disclaimers apply). This research has been financially supported by the Canada Research Chairs program and the Fondation de l'Université du Québec à Chicoutimi.

2. Myth does not exist presently as a topic of sociological analysis. The influential J. C. Alexander and Philip Smith’s "Strong Program in Cultural Sociology" (2001) contains only one mention of the word. The impressive 800-page survey volume edited by J. C. Alexander, R. N. Jacobs and P. Smith (2012) comprises 30 chapters devoted to various topics of cultural sociology, excluding myths which receive only fleeting mentions. In similar handbooks, such as L. Spillman (2002), R. Friedland and J. Mohr (2004), M. D. Jacobs and N. W. Hanrahan (2005), J. R. Hall et al. (2010), myths are practically ignored. To a large extent, the same could be said of the historical science. For instance, a programmatic collection of essays on the new cultural history (L. Hunt 1989) contains only two brief references to Greek and Roman literary myths.

3. Those are rather predictable examples. However, complications may occur. For instance, according to R. Eyerman (2001), the experience of slavery in the Afro-American community has engendered two competing ethos, one focusing on progressive racial advancement, another on restoration of the lost glory. Likewise, the Holocaust has inspired two different postwar representations, a "progressive" and a "tragic" (J. C. Alexander 2003, Chapter 2). France's memory of World War II has also produced contradictory ethos (O. Wieviorka 2012), contrary to what happened in England, Canada, or Australia where a triumphant, uplifting discourse has prevailed.

4. To give but one example, over the last two or three decades, how many public figures in Europe and North America had to apologize if not to resign after making "preposterous" statements about gender equality, sexual orientation or racial issues?

5. In the communist tradition, regular reminders of past capitalism's crimes were obviously not designed to bring about appeasement and amnesia. It has also been shown that some nations re-enact the memory of past defeats and sacrifices as a strategy to strengthen national identity (S. J. Mock 2011).

6. Institutions, labour unions, political parties, private corporations, churches... 
7. For a more detailed account of the mythification process, see G. Bouchard (2014).

8. For an illustration, see E. A. Shils (1975, Chapters 19-20). The analysis shows how military authorities can build strong and lasting identities and solidarities within army units initially made up of strangers.

9. Talking about political myths, W. L. Bennett (1980) remarks that they are such basic components of everyday perceptions that they are difficult to analyse: "They are like the lenses in a pair of glasses in the sense that they are not the things people see when they look at the world, they are the things they see with" (167).

10. As highlighted by J. C. Alexander and R. Gao (2012), individuals seek "to be faithful to their beliefs, emotionally engaged, and coherent in a moral sense” (583). Likewise, G. Sciortino's (2012) argue for the study of symbolic systems as “enabling and constraining” (379).

11. Thus, broadly defined, social myths include political myths as characterized by H. Tudor (1972), C. Flood (2001), C. Bottici (2007) and C. Bottici and B. Challand (2013).

12. I am referring primarily to The Elementary Forms of the Religious Life (1912).

13. See G. Zubrzycki (2013b), Y. Zerubavel (2013), G. Bouchard (2013).

14. Thus, the 19th century national emancipation movement in Italy linked up with very old myths built on family values (brotherhood, solidarity, honour) and Catholic symbols (Christ as a saviour and a martyr, Mary as a virgin mother...) (A. M. Banti 2000; 2005). Likewise, the 1960s Quiet Revolution in Québec was cast as congruent with the old master myths of the survival of the nation and its Francophone minority in search of advancement.

15. At a smaller scale, a similar example of contradiction is provided by the late Meiji Japan (C. Gluck 1985).

\section{Works Cited}

Alexander, Jeffrey C. The Meanings of Social Life: A Cultural Sociology. New York: Oxford University Press, 2003. 296.

Alexander Jeffrey C. and Gao Rui. "Remembrance of Things Past: Cultural Trauma, the 'Nanking Massacre', and Chinese Identity.” Eds. Jeffrey C. Alexander, Ronald N. Jacobs, and Philip Smith. The Oxford Handbook of Cultural Sociology. New York: Oxford University Press, 2012. 583-609.

Alexander Jeffrey C., Jacobs Ronald N., and Smith Philip. The Oxford Handbook of Cultural Sociology. New York: Oxford University Press, 2012. 818.

Alexander Jeffrey C. and Smith Philip. “The Strong Program in Cultural Sociology.” Ed. Jonathan H. Turner. The Handbook of Sociological Theory. New York: Kluwer, 2001. 135-50.

Balandier Georges. "Les Mythes politiques de colonisation et de décolonisation en Afrique.” Cahiers internationaux de sociologie 33 (1962): 5-20.

Banti Alberto M. La nazione del Risorgimento. Parentela, santità e onore alle origini del Risorgimento. Turin: Einaudi, 2000.214.

---. L'onore della nazione. Identità sessuali e violenza nel nazionalismo europeo dal xviii secolo alla Granda Guerra. Turin: Einaudi, 2005. 392.

Bennett W. Lance. “Myth, Ritual, and Political Control.” Journal of Communication 30.4 (1980): 166-79.

Bottici Chiara. A Philosophy of Political Myth. Cambridge: Cambridge University Press, 2007. 286.

Bottici Chiara and Challand Benoît. Imagining Europe. Myth, Memory, and Identify. Cambridge: Cambridge University Press, 2013. 205.

Bouchard Gérard. “The Small Nation with a Big Dream: Québec National Myths, 18th-20th Centuries.” Ed. Gérard Bouchard. National Myths: Constructed Pasts, Contested Presents. London: Routledge, 2013. 1-23.

---. Raison et déraison du mythe. Au cour des imaginaires collectifs. Montréal: Boréal, 2014. 234.

Cullen Jim. The American Dream: A Short History of an Idea That Shaped a Nation. New York: Oxford University Press, 2003. 214.

Eyerman Ron. Cultural Trauma: Slavery and the Formation of African American Identity. New York: Cambridge University Press, 2001. 314.

Flood Christopher. Political Myth. London: Routledge, 2001. 256.

Friedland Roger and Mohr John. Matters of Culture: Cultural Sociology in Practice. Cambridge, UK: Cambridge University Press, 2004. 408.

Gluck Carol. Japan's Modern Myths: Ideology in the Late Meiji Period. Princeton, N.J.: Princeton University Press, 1985.407.

Goffman Erving. Frame Analysis: An Essay on the Organization of Experience. New York: Harper and Row, 1974. 586.

Hall John R., Grindstaff Laura, and Lo Ming-Cheng. Handbook of Cultural Sociology. New York: Routledge, 2010. 696.

Hunt Lynn. The New Cultural History. Berkeley: University of California Press, 1989. 244. 
Jacobs Mark D. and Weiss Hanrahan Nancy. The Blackwell Companion to the Sociology of Culture. Malden, MA: Blackwell Publishing, 2005. 503.

Mock Steven J. Symbols of Defeat in the Construction of National Identity. New York: Cambridge University Press, 2011. 306.

Moscovici Serge. "The Phenomenon of Social Representations." Eds. Robert M. Farr and Serge Moscovici. Social Representations. Cambridge/Paris: Cambridge University Press/Editions de la Maison des Sciences de l'Homme, 1984. 3-69.

Polletta Francesca. It Was Like a Fever: Storytelling in Protests and Politics. Chicago: University of Chicago Press, 2006. 256.

Reddy William M. The Navigation of Feeling. A Framework for the History of Emotions. Cambridge: Cambridge University Press, 2001. 380.

Sciortino Giuseppe. "Ethnicity, Race, Nationhood, Foreignness, and Many Other Things: Prolegomena to a Cultural Sociology of Difference-Based Interactions.” Eds. Jeffrey C. Alexander, Ronald N. Jacobs, and Philip Smith. The Oxford Handbook of Cultural Sociology. New York: Oxford University Press, Chapter 14, 2012. 365-89.

Shils, Edward A. Center and Periphery: Essays in Macrosociology. Chicago: Chicago University Press, 1975. 516.

Smelser Neil. "Psychological Trauma and Cultural Trauma.” Eds. J. C. Alexander, Ron Eyerman, Bernhard Giesen, Neil Smelser, and Piotr Sztompka. Cultural Trauma and Collective Identity. Berkeley (Calif.): University of California Press, 2004. 31-59.

Spillman Lyn. Cultural Sociology. Malden, MA: Blackwell Publishers, 2002. 369.

Swidler, Ann. "Culture in Action: Symbols and Strategies.” American Sociological Review 51 (1986): 273-86.

Thiesse Anne-Marie. Ils apprenaient la France. L'exaltation des régions dans le discours patriotique. Paris: Éditions de la Maison des Sciences de l'Homme, 1997. 131.

Tudor Henry. Political Myth. New York: Praeger Publishers, 1972. 157.

Turner Jonathan H. The Handbook of Sociological Theory. New York: Kluwer, 2001. 745.

Tyrrell Ian. "The Myth(s) That Will Not Die: American National Exceptionalism.” Ed. Gérard Bouchard. National Myths: Constructed Pasts, Contested Presents. London: Routledge, 2013. 46-64.

Vlastos Stephen. "Lineages and Lessons (for National Myth Formation) of Japan’s Postwar National Myths.” Ed. Gérard Bouchard. National Myths: Constructed Pasts, Contested Presents. London: Routledge, 2013. 243-58.

Walzer Michael. Exodus and Revolution. New York: Basic Books, 1986. 192.

Wang Zheng. Never Forget National Humiliation: Historical Memory in Chinese Politics and Foreign Relations. New York: Columbia University Press, 2012. 293.

White Richard, Nelson Patricia, and Grossman James R. The Frontier in American Culture. Berkeley: University of California Press, 1994. 116.

Wieviorka Olivier. Divided Memory: French Recollections of World War II from the Liberation to the Present. Stanford: Stanford University Press, 2012. 224.

Zerubavel, Yael. “Transforming Myths, Contested Narratives: The Reshaping of Mnemonic Traditions in Israeli Culture.” Ed. Gérard Bouchard. National Myths: Constructed Pasts, Contested Presents. London: Routledge, 2013. 173-90.

Zubrzycki, Geneviève. “Aesthetic Revolt and the Transformation of National Identity in Quebec, 1960-1969.” Forthcoming in Theory and Society. (2013a)

---. "History, the National Sensorium, and the Traps of Polish Messianic Martyrology.” Ed. Gérard Bouchard. National Myths: Constructed Pasts, Contested Presents. New York: Routledge, 2013b. 110-32. 